\title{
Imprinted gene expression in the rat embryo-fetal axis is altered in response to periconceptional maternal low protein diet
}

\author{
Wing Yee Kwong, Daniel J Miller, Elizabeth Ursell, Arthur E Wild, Adrian P Wilkins, \\ Clive Osmond ${ }^{1}$, Fred W Anthony ${ }^{2}$ and Tom P Fleming \\ School of Biological Sciences, University of Southampton, Bassett Crescent East, Southampton SO16 7PX, UK, ${ }^{1} \mathrm{MRC}$ \\ Epidemiology Resource Centre, University of Southampton, Southampton General Hospital, Southampton SO16 6YD, \\ UK and ${ }^{2}$ Developmental Origins of Health and Disease Division, School of Medicine, University of Southampton, \\ Princess Anne Hospital, Southampton SO16 5YA, UK
}

Correspondence should be addressed to WY Kwong; Email: wyk@soton.ac.uk

\begin{abstract}
In our previous study, we have shown that maternal low protein diet (LPD, $9 \%$ casein vs $18 \%$ casein control) fed exclusively during the rat preimplantation period (0-4.25 day postcoitum) induced low birth weight, altered postnatal growth and hypertension in a gender-specific manner. In this study, we investigated the effect of maternal LPD restricted only to the preimplantation period (switched diet) or provided throughout gestation on fetal growth and imprinted gene expression in blastocyst and fetal stages of development. Male, but not female, blastocysts collected from LPD dams displayed a significant reduction (30\%) in $H 19$ mRNA level. A significant reduction in $H 19(9.4 \%)$ and Igf2 $(10.9 \%)$ mRNA was also observed in male, but not in female, fetal liver at day 20 postcoitum in response to maternal LPD restricted to the preimplantation period. No effect on the blastocyst expression of $I g f 2 R$ was observed in relation to maternal diet. The reduction in $H 19 \mathrm{mRNA}$ expression did not correlate with an observed alteration in DNA methylation at the $\mathrm{H} 19$ differentially methylated region in fetal liver. In contrast, maternal LPD throughout 20 days of gestation did not affect male or female $\mathrm{H} 19$ and Igf2 imprinted gene expression in fetal liver. Neither LPD nor switched diet treatments affected $\mathrm{H} 19$ and Igf2 imprinted gene expression in day 20 placenta. Our findings demonstrate that one contributor to the alteration in postnatal growth induced by periconceptional maternal LPD may derive from a gender-specific programming of imprinted gene expression originating within the preimplantation embryo itself.

Reproduction (2006) 132 265-277
\end{abstract}

\section{Introduction}

Epidemiological studies in human populations have revealed that low birth weight and reduced intra-uterine and early postnatal growth lead to the increased risk of developing adult chronic diseases including coronary heart disease, hypertension, type 2 diabetes and osteoporosis (Barker 1993, Phillips 1998). Several animal models have provided support for an early origin to the disease susceptibility. Thus, in different mammalian species, global food restriction (Woodall et al. 1996), manipulation of maternal nutrition (Langley \& Jackson 1994, Kwong et al. 2000), uterine ligation (Jansson \& Lambert 1999) or increased maternal exposure to synthetic glucocorticoid (Nyirenda et al. 1998) during gestation have been shown to alter postnatal growth and/or physiology into adult life. These observations have led to the 'Developmental Origin of Health and Disease' (DOHaD) hypothesis which proposes that the level of nutrition available during gestation influences the developmental programme through 'predictive adaptive responses' to set appropriate postnatal growth and metabolic criteria (Gluckman et al. 2005, McMillen \& Robinson 2005). However, a mismatch between gestational and postnatal nutrition will lead to adverse phenotypic consequences and increased the disease susceptibility.

The DOHaD concept may be extended by the identification of developmental 'windows' of plasticity when nutrient availability may act decisively to alter the pattern of future development. One such potential window is the preimplantation embryo when embryonic and extra-embryonic lineages are first established and segregated, and which is known to be sensitive to the environmental conditions with lasting consequences (reviewed in Khosla et al. 2001a, Thompson et al. 2001, Fleming et al. 2004a,b). Thus, we have shown that feeding pregnant rats with low protein diet (9 vs $18 \%$ 
casein) exclusively during the preimplantation period led to male offspring with altered postnatal growth rate and organ sizes and elevated systolic blood pressure, with less severe changes evidence in female offspring (Kwong et al. 2000).

In vitro culture conditions for preimplantation embryos have also been shown to alter incipient gene expression (Niemann \& Wrenzycki 2000), fetal development rate after transfer (Khosla et al. 2001b, Thompson et al. 2001, Lane \& Gardner 2003) and postnatal physiology (Young et al. 2001). In sheep and cattle, early embryo culture conditions can give a rise to large offspring syndrome (LOS) after transfer, associated with increased perinatal malformations and mortality rate (Walker et al. 1996). In addition, mouse offspring derived from cultured embryos have been shown to display altered behaviour with respect to anxiety and spatial memory compared with in vivo-derived counterparts (Ecker et al. 2004, Fernández-Gonzalez et al. 2004). Although a variety of mechanisms may associate preimplantation environment with future developmental changes, the aberrant expression of imprinted genes has been proposed to play a significant role (Young \& Fairburn 2000, Fleming et al. 2004a,b).

Imprinted genes are only expressed from either maternal or paternal alleles due to epigenetic modifications such as DNA methylation to CpG islands in regulatory domains (Delaval \& Feil 2004, Dean et al. 2005). Several studies have identified the changes in imprinted gene expression throughout the development associated with culture composition during the preimplantation period when, through zygotic genome activation mechanisms, the DNA methylation pattern may be sensitive to environmental conditions (Doherty et al. 2000, Thompson et al. 2001, Jaenisch \& Bird 2003). Thus, exposure of sheep embryos to serum leading to LOS induced the decreased fetal expression of imprinted insulin-like growth factor 2 receptor (IGF2R) transcript and the loss of methylation on the normally active maternal allele (Young et al. 2001). In mouse, fetuses produced from blastocysts cultured in the presence of fetal calf serum were lighter at embryonic day 14 and exhibited decreased insulin-like growth factor 2 (Igf2), H19 and Grb7 imprinted gene expression and an increase in Grb10 expression (Khosla et al. $2001 b$ ). Mouse preimplantation embryos cultured in Whitten's medium displayed the aberrant expression of H19 from the normally silent paternal allele due to altered methylation pattern (Doherty et al. 2000). This aberrant $\mathrm{H} 19$ expression persisted in placental tissues in mid-gestation (Mann et al. 2004). Furthermore, the culturing of mouse zygotes to the blastocyst stage in the presence of ammonium increased the level of $H 19$ gene transcription (Lane \& Gardner 2003).

Fetal growth is largely controlled by the complex IGF system. Several imprinted genes are shown to be related to expression/function of IGF2, which is paternally expressed in several tissues. The deletion of maternal $\mathrm{H} 19$ allele gives rise to pups that are $27 \%$ heavier than their wild type littermate (Leighton et al. 1995a). The level of IGF2 protein can also be regulated by IGF2R (Lau et al. 1994). Previously, studies have shown that $\mathrm{H} 19$ is very sensitive to preimplantation culture condition (Doherty et al. 2000, Lane \& Gardner 2003, Mann et al. 2004) and maternal dietary restriction altered H19 and IGF2 gene expression in fetal sheep (Brameld et al. 2000, Naimeh et al. 2001). The culturing of sheep embryos to blastocyst stage led to reduction in IGF2R transcript and protein in late gestation (Young et al. 2001). However, it is unknown whether embryo environment in vivo, through maternal LPD treatment, may similarly alter the pattern of embryonic imprinted gene expression with lasting consequences. Therefore, we examined the effect of maternal LPD fed solely during preimplantation period (switched diet) or throughout gestation (LPD) on fetal growth and the pattern of embryonic and fetal expression on these imprinted genes. For the first time, we show that maternal LPD alters blastocyst imprinted gene expression with reduced H19 mRNA evident in male embryos. A reduced expression level for $\mathrm{H} 19$ and lgf2 transcripts is also evident in day 20 male fetal liver. These changes in gene expression precede alteration in growth which is not evident until the postnatal period.

\section{Materials and Methods}

\section{Animals and treatments}

Virgin female Wistar rats were maintained in a temperature-controlled room with $12 \mathrm{~h}$ light: $12 \mathrm{~h}$ darkness cycle. At 13-14 weeks of age (200-240 g), they were mated overnight with males of the same strain and the presence of a vaginal plug was identified the following morning $(1100=$ day 0 of development). Plug-positive animals were assigned randomly to either $9 \%$ casein (low protein diet, LPD) or $18 \%$ casein (control diet) fed ad libitum (Langley \& Jackson 1994, Kwong et al. 2000). Dams were either sacrificed during the preimplantation development (day 2-4) (for blastocysts collection, total dams $=24$; $18 \%, n=11 ; 9 \%, n=13)$ or were maintained until day 20 before analysis of fetal or placental tissues (total dams $=35 ; 18 \%, n=12 ; 9 \%, n=11$; switched diet, $n=12$ ). During this time, dams were either maintained on control or LPD diets or were switched from LPD at 4.25 days (blastocyst stage) to control diet. All animal procedures were conducted in accordance with the UK Home Office Animals (Scientific Procedures) Act (1986) with the local ethics committee approval.

\section{Embryo collection}

Embryos at different stages of development were collected from oviducts or uteri between day 2 and 4 by 
flushing with $\mathrm{H} 6$ medium containing BSA $(4 \mathrm{mg} / \mathrm{ml}$, Sigma; Sheth et al. 1997). Freshly collected embryos were rapidly washed once in $\mathrm{H} 6+\mathrm{BSA}$, three times with $\mathrm{H} 6+$ polyvinyl pyrrolidone $(6 \mathrm{mg} / \mathrm{ml}$, Sigma) medium (Sheth et al. 1997) and three times with PBS. Single embryos in minimal volume $(2-5 \mu \mathrm{l})$ of PBS were then transferred to siliconised tubes, snap frozen in liquid nitrogen and stored at $-80{ }^{\circ} \mathrm{C}$ until used. Inner cell masses (ICMs) were isolated by immunosurgery from blastocysts as described (Eckert et al. 2004) prior to snap frozen in liquid nitrogen and stored at $-80^{\circ} \mathrm{C}$ until used.

\section{Isolation of Poly $A^{+}$RNA in preimplantation embryos}

Poly $\mathrm{A}^{+}$RNA was isolated from single embryos using Dynabeads Oligo (dT) ${ }_{25}$ (Dynabeads mRNA DIRECT kit, Dynal Biotech, Wirral, UK). All reagents were provided in the Dynabeads mRNA DIRECT kit unless otherwise stated. Prior to isolation, 1 pg luciferase mRNA ( $1 \mathrm{pg} / \mu \mathrm{l}$, Promega) was added to each tube containing single embryos to serve as an external standard. Single frozenstored embryos were lysed by adding $150 \mu$ l lysisbinding buffer $(100 \mathrm{mM}$ Tris- $\mathrm{HCl}, \mathrm{pH} 8.0,500 \mathrm{mM}$ $\mathrm{LiCl}, 10 \mathrm{mM}$ EDTA, $1 \%(\mathrm{w} / \mathrm{v})$ lithium dodecylsulfate (LiDS), $5 \mathrm{mM}$ dithiothreitol) and incubated at room temperature for $10 \mathrm{~min}$ before addition of $10 \mu \mathrm{l}$ washed Dynabeads Oligo $(\mathrm{dT})_{25}$ in lysis-binding buffer and incubation at room temperature for $10 \mathrm{~min}$ on a roller. The beads with bound poly $\mathrm{A}^{+}$RNA were separated employing a Dynal MPC-P-12 magnet (Dynal Biotech). The supernatant was kept for DNA extraction (see below) in order to determine the gender of the blastocyst. After two washes with $100 \mu \mathrm{l}$ wash buffer A $(10 \mathrm{mM}$ Tris- $\mathrm{HCl}$, $\mathrm{pH}$ 8.0, $0.15 \mathrm{M} \mathrm{LiCl}, 1 \mathrm{mM}$ EDTA, $0.1 \%$ (w/v) LiDS) and three washes with $100 \mu \mathrm{l}$ wash buffer B (10 mM Tris$\mathrm{HCl}, \mathrm{pH} 8.0,0.15 \mathrm{M} \mathrm{LiCl}^{1} \mathrm{mM}$ EDTA), the poly $\mathrm{A}^{+}$ RNA was eluted from Oligo $(\mathrm{dT})_{25}$ beads in $10 \mu \mathrm{l}$ nuclease-free water (Anachem, Luton, UK) by incubating at $65^{\circ} \mathrm{C}$ for $2 \mathrm{~min}$. RT was carried out using $80 \%$ of the eluted poly $\mathrm{A}^{+} \mathrm{RNA}$ in $20 \mu \mathrm{l}$ reaction comprising $1 \times \mathrm{RT}$ buffer, Sensiscript Reverse Transcriptase (Qiagen), $20 \mathrm{U}$
RNase inhibitor (Roche), $0.19 \mu \mathrm{M}$ random hexamers (Promega) and $500 \mu \mathrm{M}$ of each dNTP (Invitrogen) according to the manufacturer's instructions. To ensure the absence of DNA contamination, the remaining $20 \%$ of eluted poly $\mathrm{A}^{+}$RNA was used in the same reaction except that Sensiscript enzyme was omitted.

\section{Embryo gene expression}

Different proportions of single embryo cDNA were used for parallel PCR to detect target gene expression using specific primers (Table 1). PCR was performed in a total volume of $50 \mu \mathrm{l}$ containing $1 \times$ PCR buffer $(20 \mathrm{mM}$ Tris$\mathrm{HCl}, \mathrm{pH} 8.4,50 \mathrm{mM} \mathrm{KCl}$ ), $2 \mathrm{mM} \mathrm{MgCl} 2$ (Invitrogen), $200 \mu \mathrm{M}$ of each dNTP (Invitrogen) and 40 pmol of each primer. A hot start was used to ensure the specific amplification of the target gene. The PCR cycles involved one cycle of $94{ }^{\circ} \mathrm{C}$ for $3 \mathrm{~min}, 72{ }^{\circ} \mathrm{C}$ for $30 \mathrm{~s}$ prior to addition of $2.5 \mathrm{U}$ of Taq DNA polymerase (Invitrogen). PCR was performed for varying numbers of cycles with the denaturing step at $94{ }^{\circ} \mathrm{C}$ for $30 \mathrm{~s}$, different annealing temperatures (Table 1) for $30 \mathrm{~s}$ and extension step at $72{ }^{\circ} \mathrm{C}$ for $45 \mathrm{~s}$. After the last cycle, samples were kept at $72{ }^{\circ} \mathrm{C}$ for $10 \mathrm{~min}$. PCR products $(10 \mu \mathrm{l})$ were separated on $1 \%$ agarose gel in the presence of $1 \mu \mathrm{g} / \mathrm{ml}$ ethidium bromide and integrated density values (IDV) generated using a digitised camera system (Alpha Imager 1220) accomplished with AlphaEase software (Alpha Innotech). After subtracting the background intensity for each band, the relative abundance of a given transcript was determined as the ratio of the IDV of that transcript to IDV value of luciferase standard (Miller et al. 2003).

\section{Embryo gender determination}

After embryo poly $\mathrm{A}^{+}$RNA binding to magnetic beads in Dynabead extraction, supernatant was transferred to a microfuge tube and $350 \mu \mathrm{l}$ of nuclease-free $\mathrm{H}_{2} \mathrm{O}$ (Anachem) added. The solution was then loaded on a Microcon YM-30 column (Millipore, Watford, UK) and centrifuged at $14000 \mathrm{~g}$ for $10 \mathrm{~min}$. This procedure was

Table 1 Primers and conditions for the detection of different transcripts.

\begin{tabular}{|c|c|c|c|c|}
\hline Genes & Primer sequence $\left(5^{\prime} \rightarrow 3^{\prime}\right)$ & $\begin{array}{l}\text { Annealing temperature, cycle number } \\
\text { and amount of embryo equivalent }\end{array}$ & Product size $(b p)$ & Accession number \\
\hline $\operatorname{lgf} 2$ & $\begin{array}{l}\text { CCGTGGCATCGTGGAAGAGTG } \\
\text { GGAAGGGAAGTGGAGCAGAGA }\end{array}$ & $62{ }^{\circ} \mathrm{C}, 36$ cycles, 0.08 & 427 & X14834.1 \\
\hline $\lg 2 R$ & $\begin{array}{l}\text { TGGCTTGTATTCCTTCTGTAG } \\
\text { AGTTGTCTCCTTCCTCTCTGA }\end{array}$ & $62{ }^{\circ} \mathrm{C}, 38$ cycles, 0.16 & 455 & NM_012756 \\
\hline H19 & $\begin{array}{l}\text { TGATCGGTGTCTCGGAGAGCT } \\
\text { GACATGAGCTGGGTAGCACCA }\end{array}$ & $65^{\circ} \mathrm{C}, 36$ cycles, 0.04 & 325 & XR_000314 \\
\hline$\beta$-actin & $\begin{array}{l}\text { TGACGATATCGCTGCGCTCG } \\
\text { GTCCAGACGCAGGATGGCAT }\end{array}$ & $70^{\circ} \mathrm{C}, 33$ cycles, 0.04 & 532 & ВС063166 \\
\hline Luciferase & $\begin{array}{l}\text { ACTTCGAAATGTCCGTTCGG } \\
\text { TCCGGAATGATTTGATTGCC }\end{array}$ & $58{ }^{\circ} \mathrm{C}, 30$ cycles, 0.04 & 535 & M15077 \\
\hline$u P A$ & $\begin{array}{l}\text { GTCCTTCAGCAAACCTACAAT } \\
\text { CACCTCAAACTTCATCTCTCC }\end{array}$ & $56^{\circ} \mathrm{C}, 40$ cycles, 0.16 & 476 & NM_013085 \\
\hline
\end{tabular}


repeated two more times with $500 \mu \mathrm{l} \mathrm{H}_{2} \mathrm{O}$ added after each spin. The solution in the column was then eluted and the eluant transferred to a new YM-30 column and centrifuged at $14000 \boldsymbol{g}$ for $3 \mathrm{~min}$. Then, $20 \mu \mathrm{l} \mathrm{H}_{2} \mathrm{O}$ was added to each column and resuspended for $30 \mathrm{~s}$. DNA in the column was eluted and added to master mix containing $1 \times$ PCR buffer (as above), $1.5 \mathrm{mM} \mathrm{MgCl} 2$, $200 \mu \mathrm{M}$ of each dNTPs and $40 \mathrm{pmol}$ of each primer (Table 2). Then, samples were heated at $94{ }^{\circ} \mathrm{C}$ for $8 \mathrm{~min}, 60^{\circ} \mathrm{C}$ for $2 \mathrm{~min}$ for three cycles before the addition of $2.5 \mathrm{U}$ Taq DNA polymerase. PCR was performed for 30 cycles consisting of $94{ }^{\circ} \mathrm{C}$ for $1 \mathrm{~min}$, $60{ }^{\circ} \mathrm{C}$ for $2.5 \mathrm{~min}$ and $72{ }^{\circ} \mathrm{C}$ for $2.5 \mathrm{~min}$. After the last cycle, the samples were kept at $72{ }^{\circ} \mathrm{C}$ for another $10 \mathrm{~min}$. The first stage product $(2 \mu \mathrm{l})$ was transferred into two tubes each containing $47.5 \mu \mathrm{l}$ master mix (as above) either with 40 pmol of each Hprt and Zfy inner primers or with Sry inner primers (Table 2). After the addition of $2.5 \mathrm{U}$ Taq DNA polymerase, PCR was performed at the same conditions as described above. After the second stage PCR, $15 \mu \mathrm{l}$ product was separated in $1.8 \%$ agarose gel and DNA bands were visualised under UV illumination.

\section{Collection of fetal and placental samples}

On day 20 of gestation, conceptuses were removed from uteri and their position in the horn recorded. Each conceptus was weighed before dissecting into fetus, placenta and yolk sac and subsequently fetal organs for re-weighing. Samples were either snap frozen in liquid nitrogen or in the case of fetal liver stored in RNA later solution (Qiagen). For gene analysis in fetal liver, two fetuses were chosen randomly (prior to gender determination) from the right horn. Placental samples from these fetuses were also used for gene analysis. In addition, two placental samples were also chosen randomly (prior to gender determination) from the left horn. RNA was extracted from these samples using RNeasy Mini Kit (Qiagen). After determining the concentration by Biophotometer (Eppendorf), RNA was used in RNase protection for gene expression analysis. To determine fetal gender, DNA was extracted from liver using DNeasy Tissue kit (Qiagen) and gender determined by PCR as described above for embryos.

\section{Preparation of biotinylated riboprobes}

The PCR products of H19, Igf2, $\beta$-actin and $28 S$ rRNA from fetal liver or placenta were cloned into TOPO-2.1 vector according to manufacturer's instructions (Invitrogen). In vitro transcription was performed in a final volume of $20 \mu \mathrm{l}$ containing $1 \mu \mathrm{g}$ of linearised plasmid, $1 \times$ reaction buffer $\left(40 \mathrm{mM}\right.$ Tris, $\mathrm{pH} 7.9,6 \mathrm{mM} \mathrm{MgCl}_{2}$, $2 \mathrm{mM}$ spermidine and $10 \mathrm{mM} \mathrm{NaCl}$, Promega), $0.01 \mathrm{M}$ DTT, $2 \mathrm{mM}$ each ATP, GTP and UTP, $0.5 \mathrm{mM}$ CTP, $1 \mu \mathrm{l}$ RNase inhibitor (10 U/ $\mu \mathrm{l}$, Promega), $0.5 \mathrm{mM}$ Biotin-CTP (Amersham) and $1 \mu \mathrm{l}$ T7 RNA polymerase $(10 \mathrm{U} / \mu \mathrm{l}$, Promega). Reaction mix was incubated at $37^{\circ} \mathrm{C}$ for $1.5 \mathrm{~h}$ before treatment with RNase-free DNase I (Promega) at $37^{\circ} \mathrm{C}$ for $15 \mathrm{~min}$ and the reaction terminated by adding $1 \mu \mathrm{l} 0.5 \mathrm{M}$ EDTA. In vitro-transcribed product was separated from unincorporated nucleotides in a $7 \mathrm{M}$ urea, $6 \%$ polyacrylamide gel (Invitrogen) at $180 \mathrm{~V}$ for 50 min before visualising on Fluor-coated thin layer chromatography plate (Ambion, Huntingdon, UK) at $254 \mathrm{~nm}$. Relevant bands were excised and eluted in probe elution buffer (Ambion).

\section{RNase protection assay}

RNase protection assay was carried out using RPA III kit (Ambion). Briefly, $5 \mu \mathrm{g}$ total RNA from fetal liver or placenta was hybridised with biotinylated riboprobes (6 fmol for $\beta$-actin, H19 and lgf2 and 10.65 pmol for $28 S$ $r R N A)$ at $42{ }^{\circ} \mathrm{C}$ overnight in hybridisation III buffer as described by the manufacturer. After hybridisation, a mixture of $2.5 \mathrm{U} / \mathrm{ml}$ RNase $\mathrm{A}$ and $100 \mathrm{U} / \mathrm{ml}$ RNase T1 was added and incubated at $37^{\circ} \mathrm{C}$ for $30 \mathrm{~min}$. Protected hybrids were purified and separated on $7 \mathrm{M}$ urea, $6 \%$ polyacrylamide gel (Invitrogen) at $180 \mathrm{~V}$. A 'no RNase' (undigested probes) and 'no target' (probes hybridised with yeast RNA treated with RNase enzyme mix) controls were included in every assay to check probe integrity and the completion of enzyme digestion. Then, bands were transferred to Biodyne B membrane (Pierce, Cramlington, UK) at $30 \mathrm{~V}$ for $2 \mathrm{~h}$. Membranes were then air-dried and bands were detected using Supersignal RPA III Chemiluminescent Detection kit (Pierce) as described by the manufacturer. Band intensity was quantified using VersaDoc Imaging System and Quantity One software (Bio-Rad).

Table 2 Outer and inner primer sequences and product size for embryo and fetal gender determination.

\begin{tabular}{|c|c|c|c|}
\hline Genes & Primer sequence $\left(5^{\prime} \rightarrow 3^{\prime}\right)$ & Product size $(b p)$ & Accession number \\
\hline & Outer primers & & \\
\hline Hprt & GTTCTCTTCAАTTGCTGGTCСА TGACAACGATTCACАCTGCTGA & 618 & AF001282 \\
\hline Zfy & АAGATAAGСТTGСАТАATСАСАТGССТАТGАAАСССТTТGСТGСАСАТG & 611 & X75172 \\
\hline Sry & $\begin{array}{l}\text { CACAAGTTGGCTCAACAGAATC AGCTCTACTCCAGTCTTGTCCG } \\
\text { Inner primers }\end{array}$ & 300 & X89730 \\
\hline Hprt & ATGCTGGTGTTGTCTCTTCAGA ATCTGTCTGTCTCACAAGGGAA & 318 & \\
\hline Zfy & GGAAGCATCTTTCTCATGCTGG TTTTGAGCTCTGATGGGTGACGG & 207 & \\
\hline Sry & AGCATGCAGAATTCAGAGAT ATAGTGTGTAGGTTGTTGTCC & 248 & \\
\hline
\end{tabular}




\section{$17 \beta$-estradiol and progesterone analysis in maternal serum}

Maternal blood samples were taken by cardiac puncture on day 4 of pregnancy at the same time as blastocyst collection. The serum was prepared by centrifuging the blood at $4{ }^{\circ} \mathrm{C}, 1000 \mathrm{~g}$ for $10 \mathrm{~min}$. The $17 \beta$-estradiol was measured by the Estradiol Maia kit (Serono) and progesterone by the Amerlex-M progesterone kit (Amersham). Control sera gave inter-assay coefficients of variation for $17 \beta$-estradiol and progesterone of 9.9 and $9.4 \%$ respectively.

\section{Bisulphite mutagenesis and sequencing}

DNA from day 20 fetal liver was extracted using DNeasy Tissue kit (Qiagen) according to the manufacturer's instruction. DNA samples $(4 \mu \mathrm{g})$ were bisulphite treated as described by Warnecke et al. (1998), and bisulphitetreated DNA was dissolved in $20 \mu \mathrm{l}$ water and stored at $-20{ }^{\circ} \mathrm{C}$ until used. PCR was performed using $8 \mu \mathrm{l}$ bisulphite-treated DNA in a reaction volume of $50 \mu \mathrm{l}$ containing $2.5 \mathrm{U}$ Taq polymerase, $1 \times$ reaction buffer (Invitrogen), $2 \mathrm{mM} \mathrm{MgCl} 2,200 \mu \mathrm{M}$ of each dNTPs and 40 pmol of outer primers for $\mathrm{H} 19$ differentially methylated region (GenBank AF043428) for 30 cycles at $94{ }^{\circ} \mathrm{C}$ for $1 \mathrm{~min}, 50^{\circ} \mathrm{C}$ for $1 \mathrm{~min}$ and $72^{\circ} \mathrm{C}$ for $1 \mathrm{~min}$. Then, $2 \mu \mathrm{l}$ of first stage PCR product was amplified for another 30 cycles with the same conditions as the first stage reaction. Outer primers: (4207-4233) 5' GGTTTTTATGGTTTTTGGATTTTTAAA $3^{\prime}$ and (4873-4845) 5' AAAAACCATTCCATAAATCCAAATACCTA $3^{\prime}$. Inner primers: (4237-4270) 5' TTAGTGTGGTTTATTATTAGAAGATGTAGAAGT $3^{\prime}$ and (4844-4802) 5' TAAACCTAAATAACTTAAAACTTTATCACAAAC $3^{\prime}$. PCR products were then gel purified by QIAquick Gel Extraction kit (Qiagen) and subjected to a sequencing using ABI PRISM Big-Dye v1.1 sequencing ready reaction mix (Applied Biosystems, Warrington, UK).

\section{Statistical analysis}

Data from blastocysts were not normally distributed and were normalised by $\ln (1+x)$ transformation. The gene expression data sets included either multiple embryos or at least two fetal and placental samples from the same dam. Because of the hierarchical nature of these data, a random effects regression analysis was employed (Stata program, Stata Corporation, College Station, TX, USA), which accounts for the variance between and within dams. Additional parameters such as gender, number of fetuses in the litter and their location in individual horns may also exert an effect on gene expression and were also accounted for estimating the effect of diet on gene expression (Kwong et al. 2004, Osmond et al. 2005). Thus, data presented (mean \pm s.E.M.) as significantly different $(P<0.05)$ are independent of these parameters. Conceptus weight data were similarly analysed by random effects regression analysis.

\section{Results \\ Effect of maternal LPD on fetal and placental growth}

On day 20 of gestation, the weights of placenta, fetuses and their organs were determined and the genders of these fetuses were also recorded. Using random effects regression analysis, taking into account the variables of gender, uterine position, litter size and maternal/fetal hierarchy, no significant difference in placental, fetal or organ weights or organ/body weight ratio was detected in relation to diet treatment (Table 3).

\section{H19 expression pattern in rat embryos}

The expression pattern of $\mathrm{H} 19$ in mouse preimplantation embryos is controversial. While some reports suggest that it is not expressed until the postimplantation stage, others have indicated the expression at the blastocyst stage (Poirier et al. 1991, Szabo \& Mann 1995, Doherty et al. 2000). Therefore, we first examined the temporal and spatial expression of $\mathrm{H} 19$ and Igf2 in rat embryos (not previously investigated) from two-cell to blastocyst stages before determining the effect of maternal LPD on embryo imprinted gene expression.

H19 transcripts were first detected at the morula stage ( $\sim 16-32$ cells) with increased band intensity apparent at the blastocyst stage (Fig. 1A). This finding is consistent with those reported for mouse embryos employing RT-PCR in which a major increase in H19 mRNA was observed between eight-cell and blastocyst stages (Doherty et al. 2000). Igf2 expression was first detected at the compacted eight-cell stage (Fig. 1A).

Both in situ hybridisation and RT-PCR data on mouse blastocysts indicate $\mathrm{H} 19$ is only expressed in the trophectoderm cells (Poirier et al. 1991, Doherty et al. 2000). To determine the spatial distribution of the H19 transcript in rat blastocysts, ICMs, immediately after immunosurgical isolation, and whole blastocysts were compared. We found H19 only detectable in whole blastocysts but not ICM samples (Fig. 1B), indicating trophectoderm specificity. Furthermore, another reported trophectoderm-specific transcript, urokinase plasminogen activator (uPA) (Harvey et al. 1995), gave an equivalent result (Fig. 1B). In contrast, the amplification of Igf2 transcript was detected in both isolated ICMs and whole blastocysts (Fig. 1B). In conclusion, the results indicate that $\mathrm{H} 19$ and Igf2 exhibit distinct temporal and spatial expression profiles in rat preimplantation embryos.

\section{Gene expression analysis in blastocysts by semi-quantitative RT-PCR amplification}

Although the Dynabead method for poly $\mathrm{A}^{+} \mathrm{RNA}$ extraction and semi-quantitation has been used in single bovine embryo analyses (Miller et al. 2003), this is the first report of its use in single rat embryos. This method was selected in our study because it provided a fast and 
Table 3 Effect of maternal LPD on placental, fetal, organ weights and body proportion of day 20 rat fetuses.

\begin{tabular}{|c|c|c|c|}
\hline & $\begin{array}{c}\text { 18\% Casein } \\
(n=78, \text { dams }=14)\end{array}$ & $\begin{array}{c}\text { 9\% Casein } \\
(\mathrm{LPD})(n=64, \text { dams }=12)\end{array}$ & $\begin{array}{l}\text { 9-18\% Casein } \\
\text { (switched diet) }(n=76, \text { dams }=14)\end{array}$ \\
\hline \multicolumn{4}{|l|}{ (A) Male fetuses } \\
\hline Fetal weight (mg) & $3429 \pm 29.9$ & $3412 \pm 36.5$ & $3429 \pm 55.3$ \\
\hline Placental weight (mg) & $442.69 \pm 5.56$ & $410.10 \pm 6.35$ & $430.65 \pm 6.12$ \\
\hline Liver weight (mg) & $214.78 \pm 3.98$ & $214.47 \pm 6.66$ & $216.91 \pm 5.21$ \\
\hline Heart weight (mg) & $18.34 \pm 0.34$ & $17.64 \pm 0.33$ & $17.76 \pm 0.47$ \\
\hline Kidney weight (mg) & $27.09 \pm 0.42$ & $28.05 \pm 0.44$ & $28.03 \pm 0.55$ \\
\hline Fetal/placental weight & $7.84 \pm 0.12$ & $8.43 \pm 0.14$ & $8.03 \pm 0.13$ \\
\hline Liver/fetal weight $(\%)$ & $6.27 \pm 0.11$ & $6.25 \pm 0.17$ & $6.33 \pm 0.12$ \\
\hline Heart/fetal weight (\%) & $0.54 \pm 0.009$ & $0.52 \pm 0.008$ & $0.52 \pm 0.010$ \\
\hline \multirow[t]{2}{*}{ Kidney/fetal weight $(\%)$} & $0.79 \pm 0.011$ & $0.82 \pm 0.009$ & $0.82 \pm 0.008$ \\
\hline & $\begin{array}{c}\mathbf{1 8 \%} \text { Casein } \\
(n=82, \text { dams }=14)\end{array}$ & $\begin{array}{c}\mathbf{9 \%} \text { Casein } \\
((\mathrm{LPD}) \quad n=72, \text { dams }=12)\end{array}$ & $\begin{array}{l}\text { 9-18\% Casein } \\
\text { (switched diet) }(n=70, \text { dams }=14)\end{array}$ \\
\hline \multicolumn{4}{|l|}{ (B) Female fetuses } \\
\hline Fetal weight $(\mathrm{mg})$ & $3357 \pm 31.7$ & $3316 \pm 29.6$ & $3300 \pm 47.8$ \\
\hline Placental weight (mg) & $433.8 \pm 5.37$ & $416.5 \pm 5.56$ & $434.3 \pm 6.64$ \\
\hline Liver weight $(\mathrm{mg})$ & $211.12 \pm 4.99$ & $214.29 \pm 4.48$ & $210.60 \pm 4.85$ \\
\hline Heart weight (mg) & $18.17 \pm 0.31$ & $17.63 \pm 0.33$ & $17.87 \pm 0.40$ \\
\hline Kidney weight (mg) & $27.51+0.44$ & $27.98+0.49$ & $27.55+0.66$ \\
\hline Fetal/placental weight & $7.82 \pm 0.11$ & $8.04 \pm 0.10$ & $7.69 \pm 0.13$ \\
\hline Liver/fetal weight $(\%)$ & $6.32 \pm 0.15$ & $6.47 \pm 0.12$ & $6.36 \pm 0.14$ \\
\hline Heart/fetal weight (\%) & $0.54 \pm 0.009$ & $0.53 \pm 0.009$ & $0.54 \pm 0.010$ \\
\hline Kidney/fetal weight (\%) & $0.82 \pm 0.011$ & $0.84 \pm 0.014$ & $0.83 \pm 0.013$ \\
\hline
\end{tabular}

efficient way to extract and separate poly $\mathrm{A}^{+}$RNA from genomic DNA so that expression and gender analysis could be performed co-ordinately.

In order to compare the relative abundance of gene expression in different samples, it is important to ensure that the PCR amplification is in the linear range. cDNA generated from each individual blastocyst was separated into appropriate amounts according to that required for each of the multiple target genes analysed. PCR was then performed for each target using different cycle numbers and also repeated in two to three

A
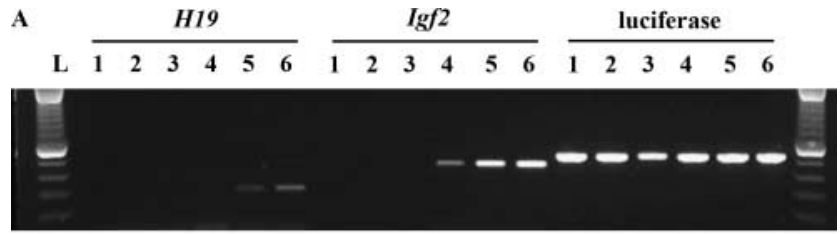

B

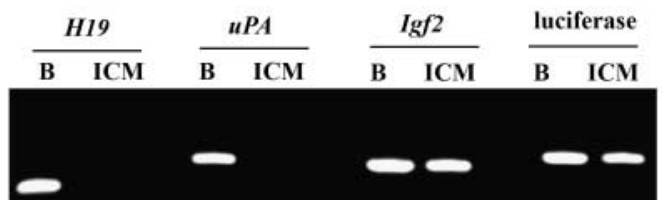

Figure 1 Temporal and spatial expression pattern of $\mathrm{H} 19$ and Igf2 during rat preimplantation embryo development. (A) H19 was first detected in morulae whereas the expression of Igf2 transcript was detected in eight-cell embryos. (B) H19 expression and urokinase plasminogen activator $(u P A)$ detection were confined to the trophectoderm lineage, whereas Igf2 was present in both lineages. Lane 1, twocell; 2, four-cell; 3, eight-cell; 4, compacted eight-cell; 5, morula and 6, blastocyst. Lane B, single blastocyst; ICM, three inner cell masses and lane L, 100 bp marker. Experiments were performed twice, in each case using two single embryos/ICM clusters ( $n=4$ in total) for all stages and similar results were obtained. different RT-PCR runs to ensure that there was no dayto-day variation. cDNA amplified for 30-38 cycles allowed the detection of individual transcripts without reaching the plateau phase of amplification. Typical semi-log plots of the amount of $\mathrm{H} 19$ and luciferase PCR products in relation to cycle number are shown in Fig. 2A and B. Cycle numbers within the linear range of amplification were selected for individual transcripts. A representative gel photograph of a RT-PCR assay of the transcripts is shown in Fig. 2C.

\section{Sex determination in single blastocysts using supernatant obtained from Dynabead extraction}

Our previous observations suggested that pregnant rats fed LPD during the preimplantation period ( $0-4.25$ days of gestation) induced a programming response in a gender-specific manner (Kwong et al. 2000). Therefore, embryo gender was determined co-ordinately with the gene expression pattern. Genomic DNA derived from single embryo supernatant after RNA extraction was screened with $X$ and $Y$ chromosome primers for Hprt, Zfy and Sry. In positive controls, $0.1 \mu \mathrm{g}$ male and female liver DNA were used. PCR product from male DNA had two bands corresponding to Hprt and Zfy fragments, while female DNA only had the Hprt fragment (Fig. 3A). In addition, male DNA showed a band corresponding to the Sry fragment in a separate PCR amplification, whereas no product was found in female DNA (Fig. 3B). Hence, rat blastocysts showing Hprt/Zfy and Sry bands were assigned as male embryos (Fig. 3 lanes 3-5) and blastocysts only with a Hprt band were assigned as female embryos (Fig. 3 lane 6). 

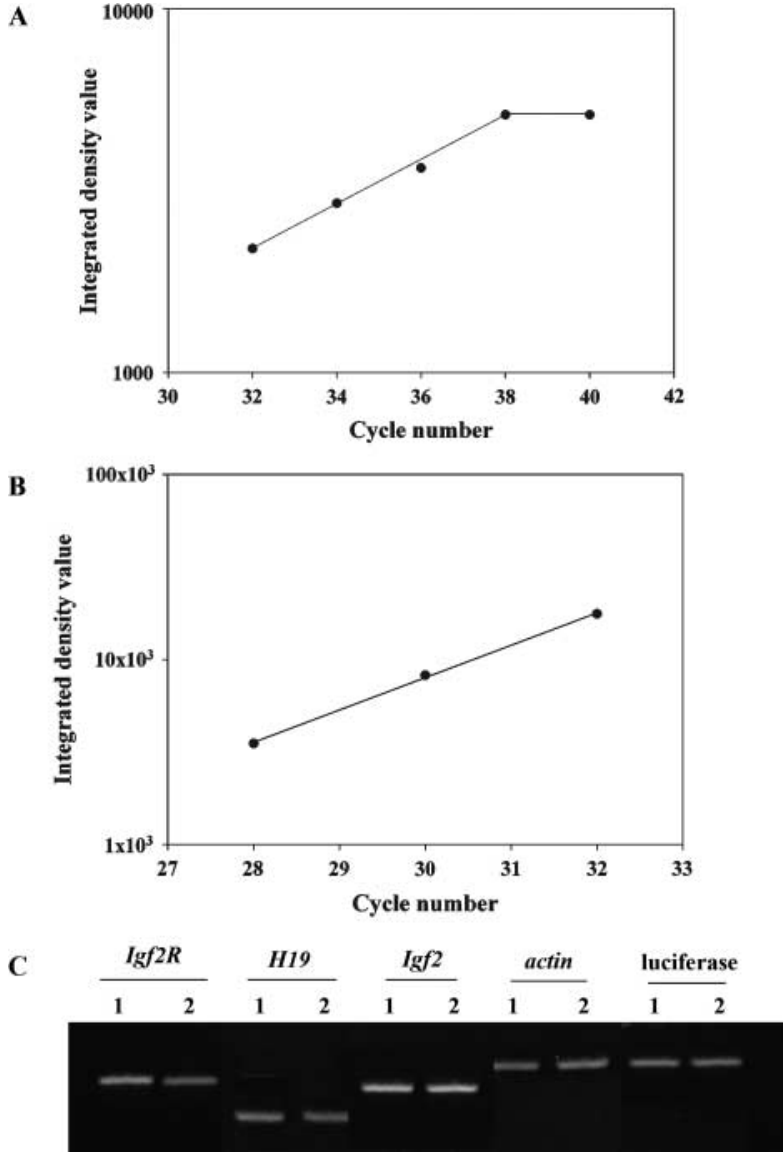

Figure 2 Validity of embryo semi-quantitative RT-PCR assay. Relationship of PCR product and cycle number for (A) H19 and (B) luciferase transcripts. (C) Gel photograph of different transcripts amplified from two single blastocyst samples (lanes 1,2).

\section{Effect of maternal LPD on imprinted gene expression in sexed blastocysts}

To determine the effect of LPD on gene expression, blastocysts were collected from the control or LPD dams on day 4 of gestation. The number of blastocysts recovered per dam were $9.09 \pm 0.53(n=11)$ and $10.31 \pm 0.49(n=13)$ for $18 \%$ casein and $9 \%$ casein dams respectively. There is no significant difference in embryos recovery number with respect to diet. After Dynabead extraction, Igf2, Igf2R, H19, $\beta$-actin and luciferase were amplified from single blastocysts (Fig. 2C). The gender of these blastocysts was also determined (Fig. $3 \mathrm{~A}$ and $\mathrm{B} ; 18 \%$, dams $=11, n=42 ; 9 \%$, dams $=13, n=47$ ).

The relative abundance of $\mathrm{H} 19$ transcript was reduced $(30 \%, P<0.05 ; 18 \%$, dams $=11, n=30 ; 9 \%$, dams $=11$, $n=28)$ in male blastocysts derived from LPD mothers (Fig. 4A). This reduction was not observed in female blastocysts (Fig. 4B; 18\%, dams $=7, n=12 ; 9 \%$, dams $=10, n=19)$. In both genders, the relative expression levels of $\lg f 2, \lg 2 R$ and $\beta$-actin transcripts were not altered by maternal LPD.

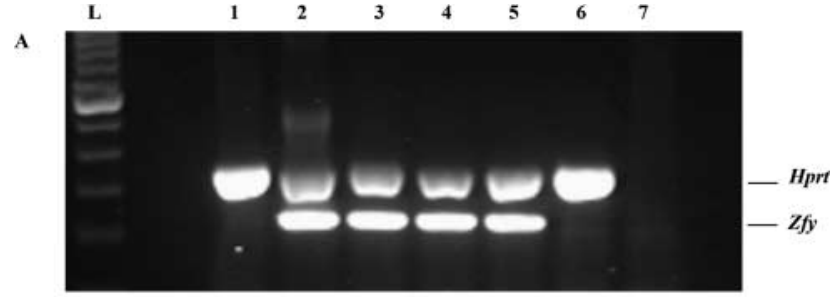

B

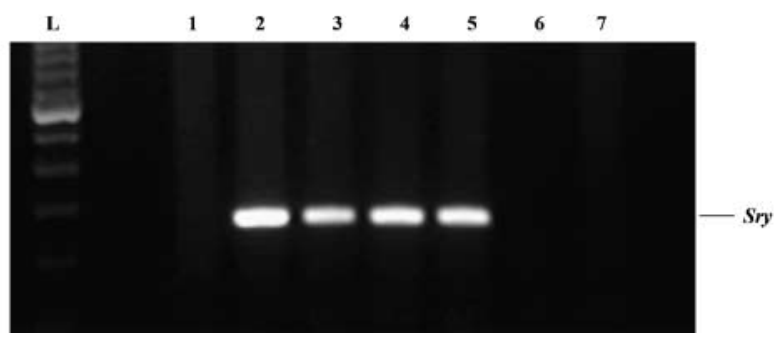

Figure 3 Sex determination in single blastocysts using supernatant obtained from Dynabead extractions. The supernatant was first purified through two YM-30 columns. Nested PCR products were electrophoresed in $1.8 \%$ agarose gel and visualised under UV illumination. (A) PCR product using Hprt and Zfy primers in nested PCR. (B) PCR product using Sry primer in nested PCR. Lane 1, $0.1 \mu \mathrm{g}$ female rat liver DNA; 2, $0.1 \mu \mathrm{g}$ male rat liver DNA. Lanes 3-6, embryo PCR product from supernatant Dynabeads extraction. Lane 7 , reagent only as negative control. L, 100 bp marker.

\section{Effect of maternal LPD on serum steroid hormones}

A previous study has shown that steroid hormones alter the expression of $\mathrm{H} 19$ gene in the uterus and in hormone-sensitive mammary MCF-7 cells (Adriaenssens et al. 1999). To investigate the possibility that reduction in $\mathrm{H} 19$ expression in blastocysts may result from alteration in maternal steroid hormone concentrations, these were measured in day 4 maternal serum. Diet did not affect the level of either $17 \beta$-estradiol (control $=$ $78.0 \pm 8.1 \mathrm{pM}(n=18) ; \mathrm{LPD}=66.7 \pm 8.0 \mathrm{pM}(n=17))$ or progesterone (control $=343.8 \pm 24.2 \mathrm{nM}(n=8) ; \mathrm{LPD}=$ $354.9 \pm 20.5 \mathrm{nM}(n=8))$.

\section{Effect of maternal LPD on gene expression in day 20 fetal liver and placenta}

Since $\mathrm{H} 19$ gene expression is reduced in male blastocysts from LPD dams, we analysed whether such changes persisted into later development. Hence, experimental dams either remained on LPD until day 20 or were switched back to control diet after preimplantation development (day 4.25). Total RNA was extracted from day 20 fetal liver and placenta, and the expression of H19, Igf2, $\beta$-actin and $28 S r R N A$ genes analysed in the same samples by multiplex RNase protection assay (Fig. 5A). The gender of these fetuses was also determined by PCR. A reduction $(P<0.05)$ in relative levels of $H 19(9.4 \%)$ and lgf2 (10.9\%) transcripts in male fetal liver from the switched diet 

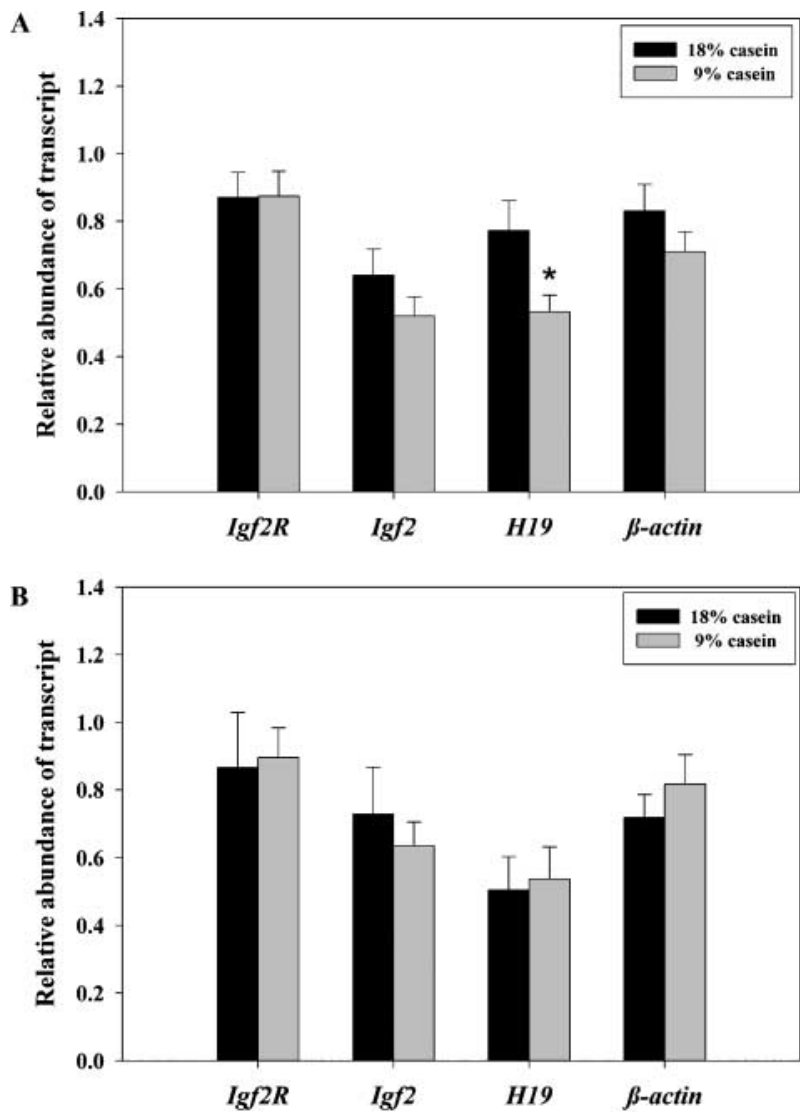

Figure 4 Relative levels of gene expression in (A) male (18\% casein, $n=30$, dams $=11 ; 9 \%$ casein, $n=28$, dams $=11)$ and (B) female $(18 \%$ casein, $n=12$, dams $=7 ; 9 \%$ casein, $n=19$, dams $=10$ ) blastocysts. Data are shown as ratio of IDV for specific transcript to IDV for luciferase. Values are expressed as mean \pm s.E.M. ${ }^{*} P<0.05$ when compared with control.

group was observed compared with controls (Fig. 5B; $18 \%$, dams $=10, \quad n=11 ; 9 \%$, dams $=10, \quad n=14$; switched diet, dams $=12, n=16$ ). In contrast, no effect on the levels of these imprinted genes was observed when LPD was maintained throughout gestation. Neither feeding regimen altered the relative expression of $\beta$-actin (Fig. 5B). No difference in gene expression was detected in female fetal liver in response to dietary manipulation (Fig. 5C; 18\%, dams $=11, n=12 ; 9 \%$, dams $=6, n=7$; switched diet, dams $=7, n=7)$. To investigate whether the reduction in $\mathrm{H} 19$ transcript correlated with the alteration in methylation status of H19 gene, bisulphite sequencing of differentially methylated region (DMR) (Manoharan et al. 2004) located upstream of the promoter was performed (Fig. 6A). By using the bisulphite treatment condition described by Warnecke et al. (1998), we found that the conversion of $\mathrm{C}$ in non-CpG to $\mathrm{T}$ is $100 \%$ (Fig. 6B). Preliminary experiments indicated that the maternal diet did not alter the methylation status of this region (Fig. 6B; $18 \%, n=3 ; 9 \%, n=3$; switched diet, $n=6$ ).
A

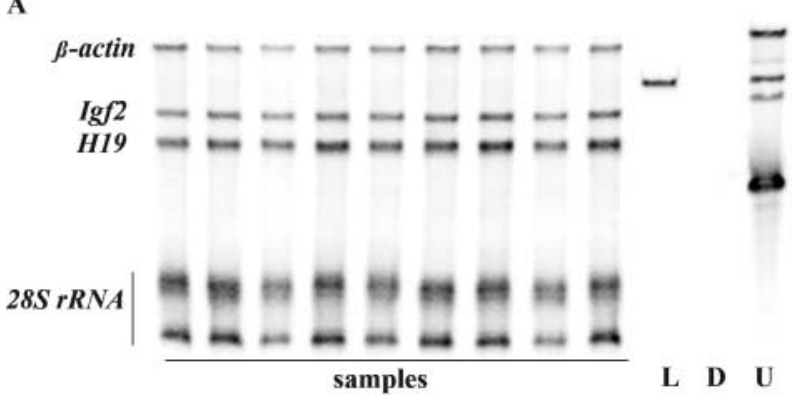

B

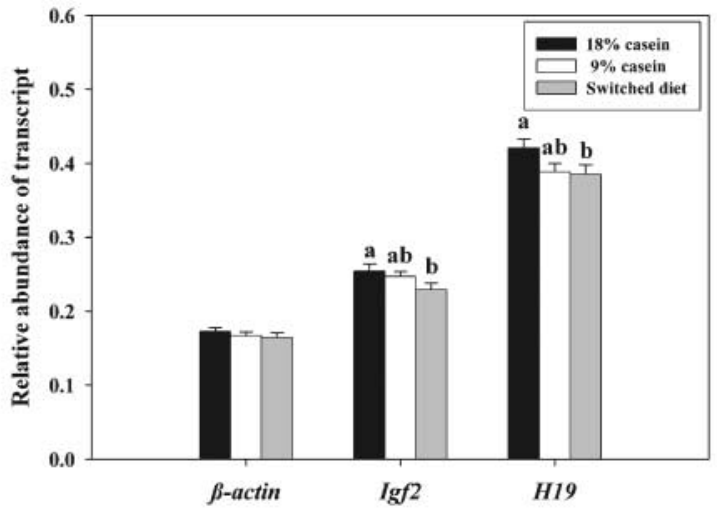

C

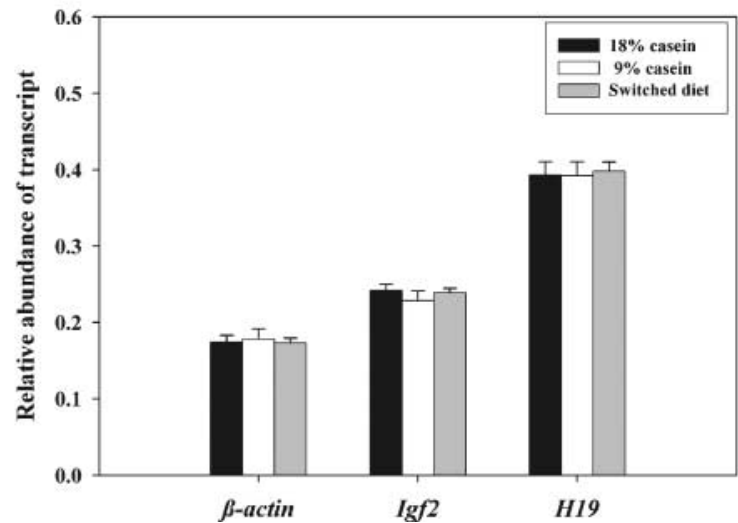

Figure 5 Relative level of gene expression in fetal liver. (A) Representative gel image of RNase protection assay. Lane D,

biotinylated probe incubated with yeast RNA and treated with RNase to verify completion of digestion. Lane $\mathrm{U}$, undigested probe. Lane L, Igf2 biotinylated probe, loaded in every gel to ensure the efficiency of chemiluminescent detection. (B) The relative abundance of genes in male liver $(18 \%$ casein, $n=11$, dams $=10 ; 9 \%$ casein, $n=14$, dams $=$ 10; switched diet, $n=16$, dams $=12)$ and $(C)$ in female liver $(18 \%$ casein, $n=12$, dams $=11 ; 9 \%$ casein, $n=7$, dams $=6$; switched diet, $n=7$, dams $=7$ ). The values were calculated as ratio of IDV of specific transcript to IDV for $28 S r R N A$. Data are mean \pm s.E.M. Different letters denote statistically significant differences, $P<0.05$.

The expression of $\mathrm{H} 19$ and Igf2 mRNA was also analysed in placenta from the same conceptuses. No differences were observed in the relative level of these genes in placenta in either sex (Fig. 7A and B; male, $18 \%$, dams $=12, n=24 ; 9 \%$, dams $=11, n=24$; switched diet, dams $=12, n=26$; female, $18 \%$, 
A

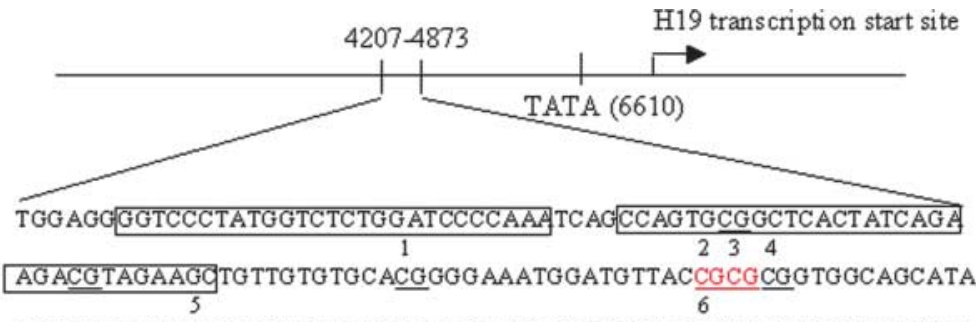

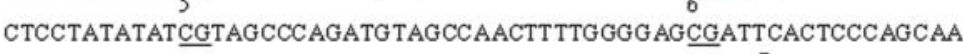

TATCCCAAGTCACCCAAACCTG ATGCAGTTCATAGGGGTGG TAAGACGTGTGCATCTCT

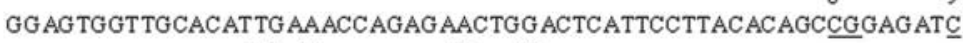
$\begin{array}{llll}10 & 11 & 12 & 13\end{array}$

GTCAATGGCTGGTATCGCCGAAATTGCCGAGCGATG ACCAGTTCAATCCCACATACTTT

AACACAGAGATGACCAAAGTTGGGGTTCACCTATGGCAAACTCAT AGGTCACTCAGGC

14

$15 \quad 16$

CTAGCGATTCACAAGGGTCATGGGGTGGTAGG ACACACATTTCTCGGGTAACTCCTTCG

17

1819

20

2122

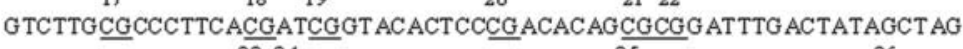

$2324 \quad 25$

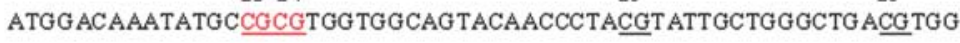

CATAGATTTGGGGTTCGCCTGTGACAAAGCTTCAAGTCACCCAGGTTCAACAAAGGGGT

CAGGCATTTGGATTTATGGAATGGTCCCDTTCTGTCTTGGGACTGCTCGCGCTAGCCAG

B $18 \%$ casein

2- - 34

NG N G G GT G G TA G UA TA TT T T TA

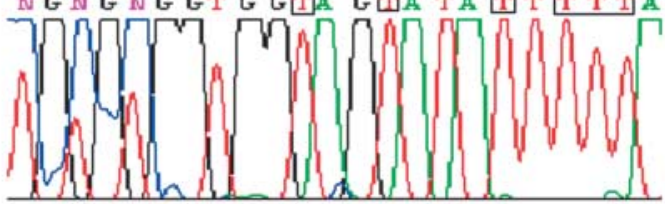

$9 \%$ casein

NG NGNGGTGGTA GTA TA T T T T TA

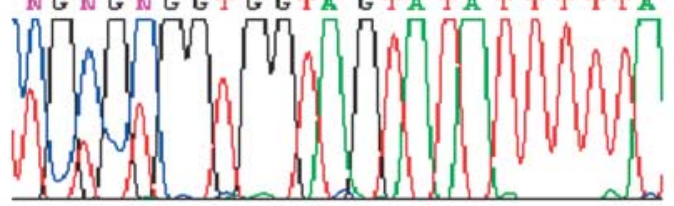

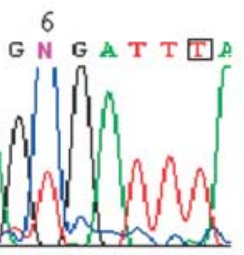

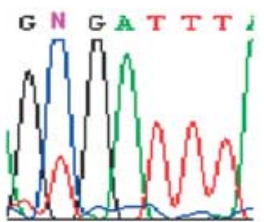

G $\mathrm{A}$ N G T

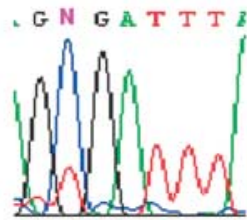

G A N G T

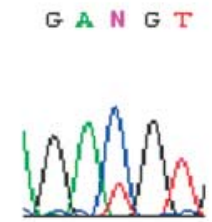

G A N G T

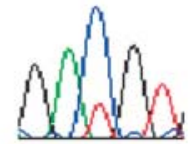

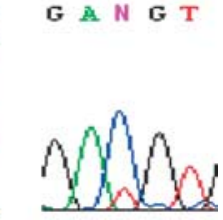

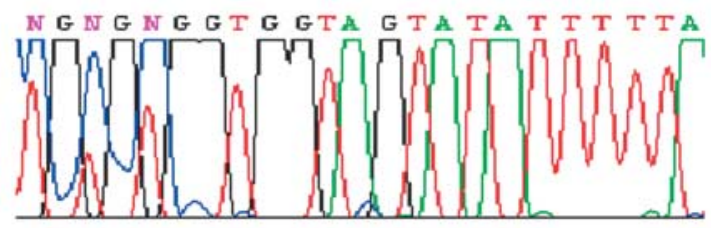

Figure 6 (A) Region of $\mathrm{H19}$ gene selected for bisulphite sequencing. $\mathrm{CpG}$ dinucleotides are numbered and underlined. Sequences within boxes are outer and inner PCR primers. CTCF sites are shown in red. (B) Representative bisulphite sequencing chromatograms of fetal liver samples. N on chromatogram indicates a mixture of $\mathrm{C}$ and $\mathrm{T}$ in DNA sequence and correspond to $\mathrm{CpG}$ sites 2, 3, 4, 6 and $7(18 \%$ casein, $n=3 ; 9 \%$ casein, $n=3$; switched diet, $n=6$ ). Bases within boxes are non-CpG cytosines that have been converted to T after bisulphite treatment.

dams $=11, n=23 ; 9 \%$, dams $=11, n=18 ;$ switched diet, dams $=11, n=19$ ).

Since $\mathrm{H} 19$ and $\lg 2$ genes contribute to growth regulation, the reduced levels of expression in response to maternal LPD may affect individual fetal growth despite the absence of effect on total fetal weight (Table 3). To test this possibility, a correlation analysis was performed on male fetal weight and the relative levels of $\mathrm{H} 19$ and Igf2 in the switched diet group. The analysis showed that there was no correlation between $\mathrm{H} 19$ or lgf2 gene expression and fetal weight $(H 19, P=0.56 ;$ lgf2, $P=0.92)$ or combined H19/lgf2 and fetal weight $(P=0.60)$. 

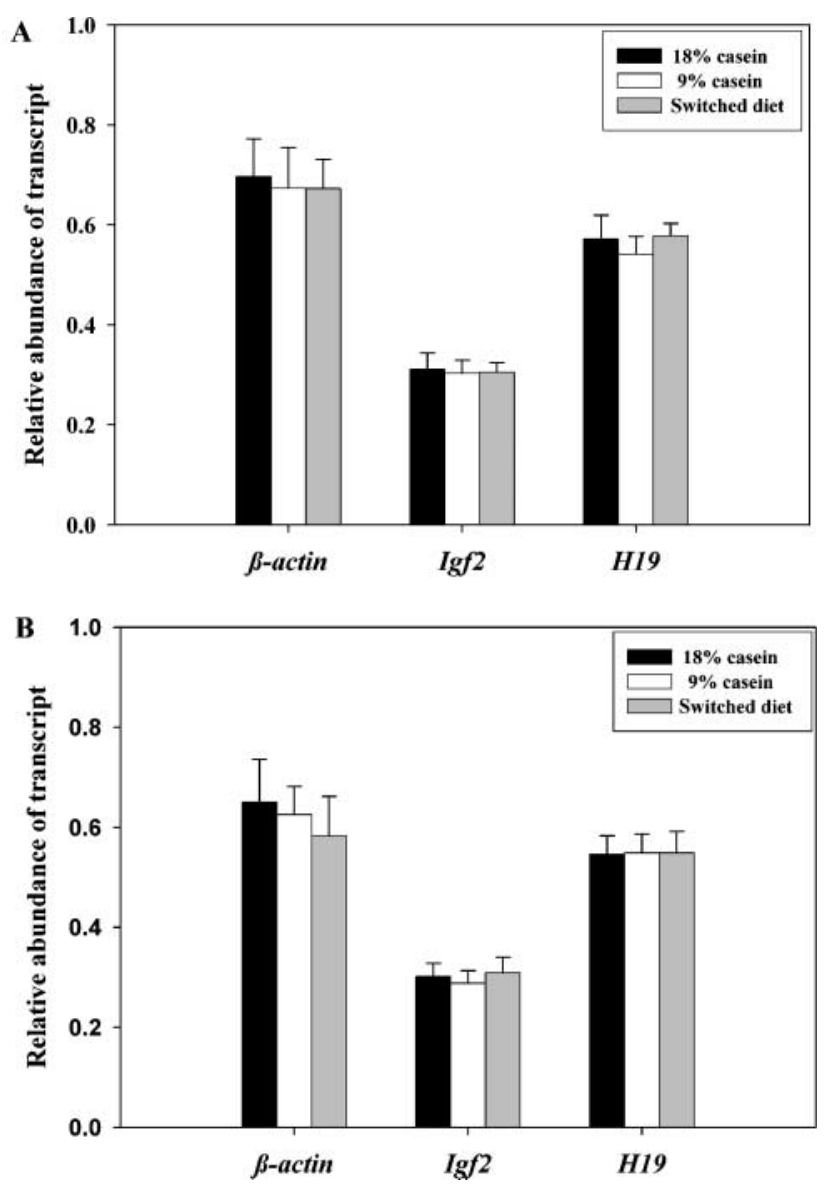

Figure 7 Relative level of gene expression in placenta. (A) male $(18 \%$ casein, $n=24$, dams $=12 ; 9 \%$ casein, $n=24$, dams $=11$; switched diet, $n=26$, dams $=12)$ and (B) female $(18 \%$ casein, $n=23$, dams $=11 ; 9 \%$ casein, $n=18$, dams $=11$; switched diet, $n=19$, dams $=11$ ). Values are calculated as ratio of IDV of particular transcript to IDV of $28 S$ rRNA. Data are mean \pm s.E.M.

\section{Discussion}

Our data show that maternal LPD fed during just the preimplantation period of rat development leads to a decrease in $\mathrm{H} 19$ imprinted gene expression in male blastocysts. At day 20 of gestation, a reduction in $\mathrm{H} 19$ and lgf2 gene expression was also observed in male fetal liver from the switched diet group (LPD only for the first 4.25 days of gestation), but not the maintained LPD group. There was no effect of any of these feeding regimens on female blastocyst or fetal liver imprinted gene expression. Similarly, the expression of these genes was not affected in placenta of either male or female conceptuses.

$\mathrm{H} 19$ belongs to a subgroup of imprinted genes that code for untranslated RNA (Brannan et al. 1990). In rat embryos, $\mathrm{H} 19$ transcript is first detected at the morula stage and only in trophectoderm cells of blastocysts. The reduction in $\mathrm{H} 19$ transcript level in male blastocysts likely reflects a specific response to maternal dietary treatment rather than a global effect on blastomere proliferation rate. Thus, rat blastocysts used in this study were collected on day 4.0 for gene expression analysis, and we have shown previously that the number of trophectoderm cells was unaffected by dietary treatment at this stage. In addition, the relative expression of $\beta$ actin, Igf 2 and $\lg 2 R$ transcripts did not show any changes in the same blastocyst. The more pronounced effect of maternal LPD on H19 compared with other genes suggests that it is more susceptible to environmental conditions. This relative sensitivity is in agreement with other reports (Doherty et al. 2000, Lane \& Gardner 2003). As H19 detection is present in trophectoderm (progenitor of most extraembryonic tissues) but not the ICM (progenitor of embryo proper) at this early stage of development, it is proposed that it plays an important role in extraembryonic tissue proliferation to support nutrient transfer and the survival of the fetus after implantation (Rossant 1986).

The analysis of $\mathrm{H} 19$ and Igf2 expression at day 20 of gestation revealed that the level of $\mathrm{H} 19$ in placenta is unaffected by dietary treatment, coinciding with no effect of maternal diet on placental weight. However, we cannot exclude the possibility that the transport function of placenta is affected at this stage or at other stages of development. Interestingly, reduction in both H19 and Igf2 transcript levels was detected in fetal liver from the switched diet group. Although it is unclear when the reduced level of these genes is initiated, it does indicate that even a brief exposure to LPD, i.e. only during the preimplantation period, may have a long-term impact on fetal phenotype, particular on $\mathrm{H} 19$ since its expression in the embryonic tissues is not initiated until day 8.5 of gestation (Poirier et al. 1991). The effect of maternal LPD during the preimplantation period appeared to be gender specific, with both male blastocysts and fetal livers being affected. Such gender-related programming effects have been observed in several studies (Kwong et al. 2000, McMullen \& Langley-Evans 2005). Although the precise mechanism is unknown, male sensitivity may reflect a faster rate of male embryo development, thus making them more vulnerable to suboptimal environmental conditions (Erickson 1997).

Several lines of evidence have suggested that DNA methylation status can be altered by maternal diet. For example, pregnant mice fed with methyl-supplemented diet containing methionine, betaine, folic acid and vitamin $B_{12}$ at conception increased DNA methylation in the intra-cisternal A particle in the $A^{v y}$ allele of agouti mice offspring (Cooney et al. 2002). In another study, Rees et al. (2000) have shown that feeding pregnant rats with LPD, which contained excess methionine relative to other amino acids, led to hypermethylation of DNA in fetal liver. However, our results in the present study indicate that DNA methylation in this particular H19 DMR was not altered by maternal diet. Thus, the aberrant expression of $\mathrm{H} 19$ in fetal livers may result from other regulatory mechanisms such as histone acetylation status 
rather than alteration in DNA methylation in this region. However, we cannot exclude the possibility that the methylation status of other regions in $\mathrm{H} 19$ gene may be affected by diet.

Expression of $\mathrm{H} 19$ and $\lg 2$ transcripts is also subjected to regulation by hormones or amino acids. In mouse uterus, it has been shown that $17 \beta$-estradiol enhances H19 expression, whereas progesterone represses it through their effect on the H19 promoter (Adriaenssens et al. 1999). In the present study, however, neither $17 \beta$ estradiol nor progesterone levels in serum from pregnant dams was affected by LPD. It is possible that other estrogenic compounds or their receptors may play a role in $H 19$ expression in blastocysts. Glucocortiocoid has also been shown to suppress $\mathrm{H} 19$ and Igf2 transcripts levels in rat neonatal liver (Senior et al. 1996) and IGF2 in fetal sheep ( $\mathrm{Li}$ et al. 1993). Given that maternal undernutrition can lead to alteration in steroid hormone levels (Gonzalez et al. 1997, Fernandez-Twinn et al. 2003), this may in turn affect $H 19$ and/or lgf2 gene expression. Amino acids have also been shown to affect the expression of genes such as $\lg f 2, \lg 2 R$ and $\lg f 1$ in preimplantation embryos (Ho et al. 1995). Moreover, alteration in maternal serum amino acid concentrations in response to LPD (Kwong et al. 2000, Petrie et al. 2002) may influence the expression of H19 (Doherty et al. 2000) and Igf2 expression (Straus \& Takemoto 1988).

H19 and lgf2 genes are thought to be regulated co-ordinately and reciprocally as described by the 'enhancer competition model' (Bartolomei et al. 1993). Based on this model, the reduction in $\mathrm{H} 19$ in both male blastocysts and fetal livers may be expected to associate with an increase in Igf2 expression. Unexpectedly, a reduction in both $\mathrm{H} 19$ and Igf2 transcript levels in blastocysts and livers was observed. Such a nonreciprocal expression of $\mathrm{H} 19$ and Igf2 has also been reported in other studies. Fetuses from mouse embryos cultured in the presence of serum had 31 and $15 \%$ reduction in $\mathrm{H} 19$ and Igf2 respectively compared with in vivo counterparts (Khosla et al. 2001b). In addition, fetal liver from pregnant ewes fasted for $48 \mathrm{~h}$ showed a $61 \%$ reduction in $\mathrm{H} 19$ without any alteration in IGF2 expression (Naimeh et al. 2001). It is possible that the expression of $\mathrm{H} 19$ and Igf2 are regulated independently under certain circumstances. In fact, the transcription of Igf2 can be modulated by the degree of methylation in DMR within the Igf2 gene (Feil et al. 1994). In addition, several studies have shown that $\mathrm{H} 19$ and Igf2 transcripts can be regulated posttranscriptionally (Straus \& Takemoto 1988, Jouvenot et al. 1999).

H19 encodes an untranslated RNA and its function remains unsolved. Some experiments suggest that it plays a growth control role (possibly via controlling IGF2 expression) during embryogenesis. Thus, deleting maternal $\mathrm{H} 19$ allele in mice led to $27 \%$ increased in birth weight compared with their wild type littermates. These animals also showed an elevated lgf2 transcript level in their tissues compared with wild type (Leighton et al. 1995a). In the present study, reduction in hepatic $\mathrm{H} 19$ and Igf2 gene expression in the switched diet group did not show any observed effect on fetal and organ weights nor did it influence the organ-to-body weight ratio. Statistical analysis also showed that there was no correlation between the decrease in expression of these genes and individual fetal growth. This may suggest that the level of reduction is insufficient to impede fetal growth. Alternatively, alteration in the availability of insulin-like growth factor binding proteins may account for the lack of effect on fetal growth (El-Khattabi et al. 2003). However, the reduction in Igf2 (and possibly protein level) and H19 may have a bigger impact on growth during the last 2 days of gestation. During this time, the weights of fetuses were nearly doubled (Langley-Evans et al. 1996). It is possible that the reduction in expression of these genes may lead to reduce weight gain or altered liver development during this rapid phase of growth. Such a possibility may explain the reduced birth weight, altered postnatal growth trajectory and reduced male offspring liver growth observed in the switched diet treatment, we have reported previously (Kwong et al. 2000). In relation to this speculation, mice with targeted disruption of Igf2 gene in liver, kidney and gut exhibit a $20 \%$ reduction in birth weight (Leighton et al. 1995b).

The effect of maternal LPD on imprinted gene expression was only seen in male fetal liver from the switched diet group but not in those fed with LPD for 20 day of gestation. The present findings are consistent with those reported by El-Khattabi et al. (2003) in which LPD fed to pregnant rats for 21.5 day of gestation did not alter Igf2 mRNA in LPD fetal liver. Although the mechanism by which maternal LPD at the preimplantation embryo stage can perpetuate into later gestation or postnatal life is unclear, it may indicate that a 'predictive adaptive response' can be initiated in the preimplantation embryo (Gluckman et al. 2005). By this concept, embryos may be able to control the growth rate or pattern of metabolism to maximise survival opportunity during future development relative to nutrient availability. However, the mismatch between preimplantation and postimplantation diets may distort such mechanisms. Consistent with this view, we have shown that programming of male hypertensive offspring can be induced irreversibly by maternal LPD fed only at the preimplanation period of development (Kwong et al. 2000).

In conclusion, our data show that maternal LPD for just the first 4 days of gestation can alter the pattern of expression of growth regulating imprinted genes from the blastocyst stage onwards. This early and maintained response to maternal LPD is gender specific and may contribute to changes in growth detected previously during the postnatal life (Kwong et al. 2000). 


\section{Acknowledgements}

We are grateful to the Medical Research Council for financial support to TPF for this research project (G9800781). We thank staff of the Biomedical Facility, University of Southampton for their technical support. The authors declare that there is no conflict of interest that would prejudice the impartiality of this scientific work.

\section{References}

Adriaenssens E, Lottin S, Dugimont T, Fauquette W, Coll J, Dupouy JP, Boilly B \& Curgy JJ 1999 Steroid hormones modulate H19 gene expression in both mammary gland and uterus. Oncogene $\mathbf{1 8}$ 4460-4473.

Barker DJ 1993 Fetal origins of coronary heart disease. British Heart Journal 69 195-196.

Bartolomei MS, Webber AL, Brunkow ME \& Tilghman SM 1993 Epigenetic mechanisms underlying the imprinting of the mouse $\mathrm{H} 19$ gene. Genes and Development 7 1663-1673.

Brameld JM, Mostyn A, Dandrea J, Stephenson TJ, Dawson JM, Buttery PJ \& Symonds ME 2000 Maternal nutrition alters the expression of insulin-like growth factors in fetal sheep liver and skeletal muscle. Journal of Endocrinology 167 429-437.

Brannan CI, Dees EC, Ingram RS \& Tilghman SM 1990 The product of the $\mathrm{H} 19$ gene may function as an RNA. Molecular and Cellular Biology 10 28-36.

Cooney CA, Dave AA \& Wolff GL 2002 Maternal methyl supplements in mice affect epigenetic variation and DNA methylation of offspring. Journal of Nutrition 132 2393S-2400S.

Dean W, Lucifero D \& Santos F 2005 DNA methylation in mammalian development and disease. Birth Defects Research. Part C, Embryo Today: Reviews 75 98-111.

Delaval K \& Feil R 2004 Epigenetic regulation of mammalian genomic imprinting. Current Opinion in Genetics \& Development 14 188-195.

Doherty AS, Mann MR, Tremblay KD, Bartolomei MS \& Schultz RM 2000 Differential effects of culture on imprinted $\mathrm{H} 19$ expression in the preimplantation mouse embryo. Biology of Reproduction 62 1526-1535.

Ecker DJ, Stein P, Xu Z, Williams CJ, Kopf GS, Bilker WB, Abel T \& Schultz RM 2004 Long-term effects of culture of preimplantation mouse embryos on behavior. PNAS 101 1595-1600.

Eckert JJ, McCallum A, Mears A, Rumsby MG, Cameron IT \& Fleming TP 2004 PKC signalling regulates tight junction membrane assembly in the pre-implantation mouse embryo. Reproduction $\mathbf{1 2 7}$ 653-667.

El-Khattabi I, Gregoire F, Remacle C \& Reusens B 2003 Isocaloric maternal low-protein diet alters IGF-I, IGFBPs, and hepatocyte proliferation in the fetal rat. American Journal of Physiology. Endocrinology and Metabolism 285 E991-E1000.

Erickson RP 1997 Does sex determination start at conception?. BioEssays 19 1027-1032.

Feil R, Walter J, Allen ND \& Reik W 1994 Developmental control of allelic methylation in the imprinted mouse Igf2 and $\mathrm{H} 19$ genes. Development 120 2933-2943.

Fernández-Gonzalez R, Moreira P, Bilbao A, Jiménez A, Pérez-Crespo $M$, Ramírez MA, De Fonseca FR, Pinado B \& Gutiérrez-Adán A 2004 Long-term effect of in vitro culture of mouse embryos with serum on mRNA expression of imprinting genes, development, and behavior. PNAS 101 5880-5885.

Fernandez-Twinn DS, Ozanne SE, Ekizoglou S, Doherty C, James L, Gusterson B \& Hales CN 2003 The maternal endocrine environment in the low-protein model of intra-uterine growth restriction. British Journal of Nutrition 90 815-822.

Fleming TP, Wilkins A, Mears A, Miller DJ, Thomas F, Ghassemifar MR, Fesenko I, Sheth B, Kwong WY \& Eckert JJ 2004a Society for
Reproductive Biology Founders' Lecture 2003. The making of an embryo: short-term goals and long-term implications. Reproduction, Fertility, and Development 16 325-337.

Fleming TP, Kwong WY, Porter R, Ursell E, Fesenko I, Wilkins A, Miller DJ, Watkins AJ \& Eckert JJ 2004b The embryo and its future. Biology of Reproduction 71 1046-1054.

Gluckman PD, Hanson MA, Spencer HG \& Bateson P 2005 Environmental influences during development and their later consequences for health and disease: implications for the interpretation of empirical studies. Proceedings in Biological Sciences 272 671-677.

Gonzalez CG, Garcia FD, Fernandez SF \& Patterson AM 1997 Role of 17-beta-estradiol and progesterone on glucose homeostasis: effects of food restriction $(50 \%)$ in pregnant and non-pregnant rats. Journal of Endocrinological Investigation 20 397-403.

Harvey MB, Leco KJ, rcellana-Panlilio MY, Zhang X, Edwards DR \& Schultz GA 1995 Proteinase expression in early mouse embryos is regulated by leukaemia inhibitory factor and epidermal growth factor. Development 121 1005-1014.

Ho Y, Wigglesworth K, Eppig JJ \& Schultz RM 1995 Preimplantation development of mouse embryos in KSOM: augmentation by amino acids and analysis of gene expression. Molecular Reproduction and Development 41 232-238.

Jaenisch R \& Bird A 2003 Epigenetic regulation of gene expression: how the genome integrates intrinsic and environmental signals. Nature Genetics 33 245-254.

Jansson T \& Lambert GW 1999 Effect of intrauterine growth restriction on blood pressure, glucose tolerance and sympathetic nervous system activity in the rat at 3-4 months of age. Journal of Hypertension 17 1239-1248.

Jouvenot Y, Poirier F, Jami J \& Paldi A 1999 Biallelic transcription of Igf2 and H19 in individual cells suggests a post-transcriptional contribution to genomic imprinting. Current Biology 9 1199-1202.

Khosla S, Dean W, Reik W \& Feil R 2001a Culture of preimplantation embryos and its long-term effects on gene expression and phenotype. Human Reproduction Update 7 419-427.

Khosla S, Dean W, Brown D, Reik W \& Feil R 2001b Culture of preimplantation mouse embryos affects fetal development and the expression of imprinted genes. Biology of Reproduction 64 918-926.

Kwong WY, Wild AE, Roberts P, Willis AC \& Fleming TP 2000 Maternal undernutrition during the preimplantation period of rat development causes blastocyst abnormalities and programming of postnatal hypertension. Development 127 4195-4202.

Kwong WY, Osmond C \& Fleming TP 2004 Support for Barker hypothesis upheld in rat model of maternal undernutrition during the preimplantation period: application of integrated 'random effects' statistical model. Reproductive Biomedicine Online 8 574-576.

Lane M \& Gardner DK 2003 Ammonium induces aberrant blastocyst differentiation, metabolism, $\mathrm{pH}$ regulation, gene expression and subsequently alters fetal development in the mouse. Biology of Reproduction 69 1109-1117.

Langley SC \& Jackson AA 1994 Increased systolic blood pressure in adult rats induced by fetal exposure to maternal low protein diets. Clinical Science 86 217-222.

Langley-Evans SC, Gardner DS \& Jackson AA 1996 Association of disproportionate growth of fetal rats in late gestation with raised systolic blood pressure in later life. Journal of Reproduction and Fertility 106 307-312.

Lau MM, Stewart CE, Liu Z, Bhatt H, Rotwein P \& Stewart CL 1994 Loss of the imprinted IGF2/cation-independent mannose 6-phosphate receptor results in fetal overgrowth and perinatal lethality. Genes and Development 8 2953-2963.

Leighton PA, Ingram RS, Eggenschwiler J, Efstratiadis A \& Tilghman SM 1995a Disruption of imprinting caused by deletion of the $\mathrm{H} 19$ gene region in mice. Nature 375 34-39.

Leighton PA, Saam JR, Ingram RS, Stewart CL \& Tilghman SM 1995b An enhancer deletion affects both $\mathrm{H} 19$ and lgf2 expression. Genes and Development 9 2079-2089. 
Li J, Saunders JC, Gilmour RS, Silver M \& Fowden AL 1993 Insulin-like growth factor-II messenger ribonucleic acid expression in fetal tissues of the sheep during late gestation: effects of cortisol. Endocrinology 132 2083-2089.

Mann MR, Lee SS, Doherty AS, Verona RI, Nolen LD, Schultz RM \& Bartolomei MS 2004 Selective loss of imprinting in the placenta following preimplantation development in culture. Development $1313727-3735$.

Manoharan H, Babcock K \& Pitot HC 2004 Changes in the DNA methylation profile of the rat $\mathrm{H} 19$ gene upstream region during development and transgenic hepatocarcinogenesis and its role in the imprinted transcriptional regulation of the $\mathrm{H} 19$ gene. Molecular Carcinogenesis 41 1-16.

McMillen IC \& Robinson JS 2005 Developmental origins of the metabolic syndrome: prediction, plasticity, and programming. Physiological Reviews 85 571-633.

McMullen S \& Langley-Evans SC 2005 Maternal low-protein diet in rat pregnancy programs blood pressure through sex-specific mechanisms. American Journal of Physiology. Regulatory, Integrative and Comparative Physiology 288 R85-R90.

Miller DJ, Eckert JJ, Lazzari G, Duranthon-Richoux V, Sreenan J, Morris D, Galli C, Renard JP \& Fleming TP 2003 Tight junction messenger RNA expression levels in bovine embryos are dependent upon the ability to compact and in vitro culture methods. Biology of Reproduction 68 1394-1402.

Naimeh LG, Schutte BC, Hamilton WS \& Tsalikian E 2001 Ontogeny of the $\mathrm{H} 19$ gene in sheep and effect of maternal fasting on its expression in the fetus. Endocrine Research 27 417-431.

Niemann H \& Wrenzycki C 2000 Alterations of expression of developmentally important genes in preimplantation bovine embryos by in vitro culture conditions: implications for subsequent development. Theriogenology 53 21-34.

Nyirenda MJ, Lindsay RS, Kenyon CJ, Burchell A \& SeckI JR 1998 Glucocorticoid exposure in late gestation permanently programs rat hepatic phosphoenolpyruvate carboxykinase and glucocorticoid receptor expression and causes glucose intolerance in adult offspring. Journal of Clinical Investigation 101 2174-2181.

Osmond C, Kwong WY \& Fleming TP 2005 Statistical analysis of data in support of the Barker hypothesis, advantages of using random effects regression model in hierarchical data. Reproductive Biomedicine Online 10 152-153.

Petrie L, Duthie SJ, Rees WD \& McConnell JM 2002 Serum concentrations of homocysteine are elevated during early pregnancy in rodent models of fetal programming. British Journal of Nutrition 88 471-477.

Phillips DI 1998 Birth weight and the future development of diabetes. A review of the evidence. Diabetes Care 21 (Supplement 2) B150-B155.

Poirier F, Chan CT, Timmons PM, Robertson EJ, Evans MJ \& Rigby PW 1991 The murine H19 gene is activated during embryonic stem cell differentiation in vitro and at the time of implantation in the developing embryo. Development 113 1105-1114.
Rees WD, Hay SM, Brown DS, Antipatis C \& Palmer RM 2000 Maternal protein deficiency causes hypermethylation of DNA in the livers of rat fetuses. Journal of Nutrition 130 1821-1826.

Rossant J 1986 Development of extraembryonic cell lineages in the mouse embryo. In Experimental Approaches to Mammalian Embryonic Development, pp 97-120. Eds J Rossant \& RA Pedersen.

Senior PV, Tucci J, Blythe NL \& Beck F 1996 Expression of IGF-II and H19 mRNA in the neonatal rat during normal maturation and after dexamethasone administration. Journal of Molecular Endocrinology 17 217-223.

Sheth B, Fesenko I, Collins JE, Moran B, Wild AE, Anderson JM \& Fleming TP 1997 Tight junction assembly during mouse blastocyst formation is regulated by late expression of ZO-1 alpha + isoform. Development 124 2027-2037.

Straus DS \& Takemoto CD 1988 Amino acid limitation negatively regulates insulin-like growth factor-II mRNA levels and E-domain peptide secretion at a post-transcriptional step in BRL-3A rat liver cells. Journal of Biological Chemistry 263 18404-18410.

Szabo PE \& Mann JR 1995 Allele-specific expression and total expression levels of imprinted genes during early mouse development: implications for imprinting mechanisms. Genes and Development 9 3097-3108.

Thompson SL, Konfortova G, Gregory RI, Reik W, Dean W \& Feil R 2001 Environmental effects on genomic imprinting in mammals. Toxicology Letters 120 143-150.

Walker SK, Hartwich KM \& Seamark RF 1996 The production of unusually large offspring following embryo manipulation: concepts and challenges. Theriogenology 45 111-120.

Warnecke PM, Mann JR, Frommer M \& Clark SJ 1998 Bisulfite sequencing in preimplantation embryos: DNA methylation profile of the upstream region of the mouse imprinted $\mathrm{H} 19$ gene. Genomics $\mathbf{5 1}$ 182-190.

Woodall SM, Johnston BM, Breier BH \& Gluckman PD 1996 Chronic maternal undernutrition in the rat leads to delayed postnatal growth and elevated blood pressure of offspring. Pediatric Research $\mathbf{4 0}$ 438-443.

Young LE \& Fairburn HR 2000 Improving the safety of embryo technologies: possible role of genomic imprinting. Theriogenology 53 627-648.

Young LE, Fernandes K, McEvoy TG, Butterwith SC, Gutierrez CG, Carolan C, Broadbent PJ, Robinson JJ, Wilmut I \& Sinclair KD 2001 Epigenetic change in IGF2R is associated with fetal overgrowth after sheep embryo culture. Nature Genetics 27 153-154.

Received 17 November 2005

First decision 2 February 2006

Revised manuscript received 9 April 2006

Accepted 22 May 2006 